1998

\title{
Taking It Personally: Legal Ethics and Client Selection
}

Allan C. Hutchinson

Osgoode Hall Law School of York University, ahutchinson@osgoode.yorku.ca

Source Publication:

Legal Ethics. Volume 1, Number 2 (1998), p. 168-183.

Follow this and additional works at: https://digitalcommons.osgoode.yorku.ca/scholarly_works c) (i) $(9)$

This work is licensed under a Creative Commons Attribution-Noncommercial-No Derivative Works 4.0 License.

\section{Recommended Citation}

Hutchinson, Allan C. "Taking It Personally: Legal Ethics and Client Selection." Legal Ethics 1.2 (1998): 168-183. 


\title{
Taking It Personally: Legal Ethics and Client Selection
}

\author{
ALLAN C. HUTCHINSON ${ }^{1}$
}

A couple of years ago, I taught a class on legal ethics. In typical fashion, I began by throwing out a crude hypothetical. It went something along the lines that, as a young lawyer, your client tells you that he has discovered that he is HIV-positive (which has not developed into full-blown AIDS) from a botched injection by his doctor. He requests you to negotiate a settlement on his behalf. Negotiations proceed quickly and the doctor's lawyers seem willing to settle for a sizeable amount. Shortly before finalising the settlement, the client informs you that he has had a second medical examination and this has conclusively revealed that he is not HIV-positive. However, he insists that he still wants you to continue the negotiations on the basis that he is HIV-positive and to take the settlement on offer. What do you do? What should you do? To my considerable surprise, a significant number of students insisted that they should follow their client's instructions: it was for the doctor's lawyer to ascertain whether or not your client is telling the truth. Moreover, in doing so, most contended that not only would they not be acting unethically, but that they would actually be fulfilling the special moral obligations of lawyers to put their clients ahead of all others. After some discussion, most students were reassured that such a course of action would not only be unethical, but also tantamount to fraud. Nonetheless, a few still persisted in protesting the moral innocence of the lawyer, whatever the ethical impropriety of the client's instructions.

This incident galvanised me in my belief that the appreciation of legal ethics and professional responsibility was very low and in need of revitalisation. The fault in the situation was less that of the students and more that of the legal community, including 
lawyers, professors, judges and administrators. How ever wrong-headed the students were, their response reflected a common misunderstanding about legal ethics and professional responsibility-that lawyers are simply glib actors who do the bidding of their directorial clients. The general view seemed to be that, when acting as lawyers, people should set aside their own moral values and expectations and replace them with a professional ethic that was exhausted by the simple maxim that 'you should be a zealous advocate for your clients' interests'. The suggestion that lawyers might import some of their own personal values into their professional practice was considered, at best, inconvenient and, at worst, inappropriate. Consequently, it seemed more urgent than ever to challenge this received wisdom and interrogate the traditional understandings of appropriate legal practice and to recommend a more appealing sensibility and approach to the ethical responsibilities of legal professionals.

Accordingly, this short essay is a preliminary and modest effort to suggest a different and less traditional contribution to debates around on legal ethics and professional responsibility. The driving ambition is to redeem the ethical possibilities that the legal profession presently seem to honour more in the breach than the observance. To do this, I introduce and defend the need to develop a more rigorous and demanding sense of professional judgement. After sketching the basic thrust of such an invigorated practice, I illustrate its workings and possible implications by reference to the largely neglected topic of client selection. Moreover, I want to do this by using a method that is more conducive to the fact that matters of legal ethics and professional responsibility should be dealt with in a contextualised and particularised way, rather than by reference to abstract and generalised norms. Although I intend to be focused and rudimentary, my discussion is part of a larger project that has a more ambitious objective. Heeding Lord Bolingbroke's caution that "the profession of law, in its nature the noblest and most beneficial to mankind, is in its abuse an abasement of the most sordid and pernicious kind," 2 I want to advise young (and old) lawyers against the temptation to professional abasement in the belief that it is done for the most noble and beneficial of professional 
causes. Legal ethics and professional responsibility can be 'most beneficial to mankind' when lawyers take them seriously as issues of personal as well as professional good character.

\section{Beyond Rules}

The term 'ethics' is derived from the Greek ethike which was used to denote the science of character. This was not considered to be solely or even mainly a matter of ruleforming, but involved the development of a personal faculty of good judgement that would respond to as well be refined in particular situations. Rules and professional codes assume that lawyers have good character and can go about their lawyering lives with an ability to apply those rules wisely and appropriately. This is the idea of professionalism. Although it has become almost perjorative in popular usage and resonance, the idea of professional

judgement is important; it involves more than the technically adept performance of a particular task, without any concern for its broader redeeming qualities or impact. As I use it, professionalism is an approach or attitude that embodies a justification for a particular course of conduct within a wider account of a morally defensible modus vivendi. It has a vital moral dimension that defines who lawyers are and what they aspire to be individually and collectively. It is not simply a vague and general aspiration, but entails a definite response to issues like the availability of legal services, the clients one accepts, the causes one pursues, etc.

A large part of that professional responsibility is to recognise that, except in the most egregious circumstances, there is no one clear role to fill and no obvious action to take; there is only the obligation to decide what that role should be for you and what action should be taken by you. While this critical process will be heavily influenced by professional codes and the values of the informing collegial community, it is a personal responsibility that involves, but does not reduce to, professional norms: "lawyer morality is ordinary morality which takes into consideration the moral value of professional obligations. ${ }^{13}$ In striving to cultivate such a practical ethic of professional 
judgement, it must not be forgotten that this is not equivalent to an ethic of principle in which ethical conduct is vouchsafed by the strong adherence to accepted and general codes. Character is reflected in all we do and what we do affects our character; it is a life-long process of development, re-adjustment and determination.

One critic who has lamented the demise of professional standards is Anthony Kronman. For him, the rationalisation and commercialisation of legal practice has led, within the profession, to disenchantment with the "lawyer-statesman" ideal that used to dominate and inform good lawyering. This ideal put great emphasis on a practical wisdom that both informed and transcended code-following or rule-adherence, and on the commitment to a shared set of communal ends. ${ }^{4}$ For Kronman, the talent of good judgment is radically inegalitarian not only in the sense that it is unevenly distributed, but also in that it is conducive to a political fraternity that recognises that the legal community has a special responsibility and facility, as a trained elite, to do what is best for society at large. While Kronman is on to something when he urges greater attention to the development of practical wisdom and professional judgment, there is no reason at all why the cultivation of such attributes needs to be associated with such an elitist vision of the legal profession. Although it is true that judgment is a difficult quality to teach and acquire, it is not the god-given gift that Kronman and others imply. To adhere to such a position not only discourages people from seeking to enter the legal profession, but also excuses those without good judgment from taking responsibility for what they do and from working to improve their skill of judgment. Unlike Kronman, I believe that 'practical judgment' is less a character trait that people either do or do not possess and more a learned skill that people can be taught, and can refine for themselves with practice.

In teaching legal ethics and professional responsibility, therefore, considerable attention must be devoted to simulating situations in which lawyers can build moral character and good judgment. As Aristotle insisted, these attributes are developed by engaging in practical situations and reflecting critically on those experiences so as to 
enhance and refine their sense of judgment. ${ }^{5}$ Consequently, this suggests that the achievement of moral character and good judgement cannot be attained by feeding students the relevant rules and a sense of the theoretical models; theory cannot substitute for practice and logic cannot replace judgment. This does not mean that theory has no place, but it cannot dispense with the need for learning by immersion in practical situations and by the development of a context-sensitive sense of applied judgment. ${ }^{6}$ It cannot be taught, but needs to be learnt in a trial-and-error way that has a built-in component of critical reflection and collegial dialogue. Instruction will need to contain a clinical element if it is to have any prospect of nurturing a sense of good judgment in law students and lawyers; it will not be sufficient to urge upon neophytes the necessity to develop good character, without some structured and supervised opportunities to cultivate a talent for making good decisions. The obvious virtue of ethical principles is often belied by the complexity of practical situations; obligation and duty are not on/off concepts, but vary in weight and force depending on the context. Moreover, 'doing the right thing' will not always be apparent or persuasive to others.

In recommending the importance of professional judgment, I take issue with the traditional image of the ethical lawyer which instructs lawyers to subordinate their personal morality and identity to the standardised requirements of a role-defined and rule-based morality. This expects that legal professionals will appreciate and actualise the demands of a role-differentiated morality in which lawyers' duties are exclusively bound by the law and the professional code of conduct on one side and the client's interests on the other. As such, it assumes a two-dimensional moral universe in which lawyers are no more expected to intrude their own personal values than actors or butlers in the performance of their duties. ${ }^{7}$ Such a notion allows persons to claim moral legitimacy for actions that might be considered illegitimate in other different roles and contexts. ${ }^{8}$ Moreover, in this professional role, lawyers are required to treat morality in the same way that they deal with law-as an exhaustive body of rules that 
can be formally applied to resolve the most recalcitrant of difficulties and dilemmas. Consequently, in the traditional approach, there is very little space for reflection or engagement; reference to the professional codes is intended to provide definitive and authoritative answers.

To read most codes of professional conduct is to encounter a series of pronouncements that are long on righteous aspiration and vague generalities, but short on serious instruction and concrete guidance. It is a case of not seeing the ethical forest for the law-like trees. Although lawyers are weighed down with discrete and detailed directives on particular matters, there is little to counsel the floundering or jaded lawyer in establishing an overall and professional modus vivendi. Like the formalist lawyering that many claim to embody and extol, ethics is reduced to a technical compliance with a set of simple do's and don'ts. It is more of a shopping list than a genuine effort to inculcate a style and substance of legal practice that addresses the whole lawyer, not merely the occasional legal transaction. It is as much about conformity as it is about conscience. Lawyers approach ethics in the same way that they approach law-as a set of rules to be mastered and manipulated to serve the purpose in hand. Indeed, under the sway of a legalistic mentality, the teaching of legal ethics and responsibility is more like a course on office management; it is as much about techniques in filing and organisation as it is about thinking through dilemmas and difficulties.

Even assuming that the various codes are treated as representing a serious attempt at ethical instruction and control, an exclusive concentration on the rules is misplaced. There is little to be gained by providing an elaborate and exhaustive annotation of the rules of professional conduct because, not only has this been adequately done, but it ignores the very real fact that the influence on lawyers' daily routines and rituals is small: the constant attention to and re-drafting of the rules is of decreasing marginal utility. ${ }^{9}$ Nevertheless, this does not mean that the codes have no place in any appreciation of legal ethics and their actual improvement. They are an important resource in discussion and 
decision-making, but they are not a decisive or determinate play-book that relieves lawyers of the personal responsibility to develop an ethical style and substance of legal practice. The codes are a site at which ethical debate can be joined and developed. As with many catalogues of rights and responsibilities, there will be competing and occasionally contradictory imperatives; duties to clients might suggest a different course of action to those recommended by the lawyers' responsibilities as an officer of the court. In some instances, the rules demand that lawyers 'must' make certain choices and give priority to certain actions. However, the rules more often offer no definite resolution and simply provide a rudimentary framework within which lawyers can debate and develop an ethical practice of law. It is important, therefore, to remember that the rules do not and cannot relieve lawyers of the continuing responsibility to exercise their own professional and moral judgement about the appropriate course to follow.

As presently practised, legal ethics is too easily reducible to an unthinking compliance with the prevailing Rules of professional conduct in order to avoid discipline or disrepute. Indeed, the Rules are rarely referenced and it is more common for practitioners to resort to personal conscience in order to determine what is a professionally appropriate course of action. ${ }^{10}$ Like general ethics, legal ethics is contextual in the sense that it involves particular people in particular situations making difficult decisions with particular time constraints, with imperfect information, and with particular consequences for particular people. And, of course, there is no context of contexts that allows people to fix onceandfor-all their obligations and actions when acting in personal or professional roles. There are few right answers that stand outside any context or debate. The traditional understandings and expectations are nothing more (or less) than the accumulated practices of lawyers that have been affixed with institutional authority. Lawyers can and should contribute as much as respond to the developing culture of lawyering. In this way, they are in a better position to cultivate a modus vivendi that enables them to bring together the promptings of their personal conscience with the demands of their professional occupation. Legal ethics ought to be an active meditation on law and 
lawyering rather than a passive and neutral adherence to a professional code. Indeed, the rules are less a set of directives from which lawyers can draw clear guidance than a collection of practical wisdom which lawyers can engage with and contest. ${ }^{11}$ Accordingly, compliance with law, in both its spirit and letter, does not amount to acceptable ethical behaviour: professional morality is more than law-abiding conformity.

\section{Professional Judgment}

The fact that most legal decisions and ethical practices by lawyers allow for a variety of manoeuvres or results means that lawyers need to develop a professional facility to comprehend and handle such challenges. There is rarely an obvious or incontestable path to follow. As much modern ethical theorising insists, what counts as acting ethically will always be a contextual question. It bears repeating that there is no universal context that allows people to fix once-and-for-all the obligations and actions of the ethically-aware lawyer. In a world of shifting contexts, there is an even greater need to develop a sense of moral judgement that can respond flexibly and firmly to the different challenges that lawyers face in their professional lives. None of this should be taken to mean that ethical behaviour and decision-making is condemned to be irrational or arbitrary, only that what counts and operates as reason is never outside of its informing context. Moreover, the alleged uncertainty of a contextual approach is no more or less inefficient than compliance with any other legal standard; certainty is not a virtue in and of itself. For instance, in determining whether their professional conduct meets the tortious standards of negligence, lawyers are accustomed to engage in a similar kind of contextualised judgement and assessment. ${ }^{12}$

In this way, legal ethics can be viewed less as a fixed and independent code of professional conduct and more as continuing practice within which lawyers construct acceptable norms of behaviour as they struggle to comply with them. Also, there is always the personal ethical challenge of determining whether, because the Rules allow certain conduct, the individual lawyer should reflect on, and perhaps refuse to operate in, 
certain ways. The fact that the Rules allow lawyers to ignore the interests of other parties entirely does not mean that it is a morally unimpeachable course to follow: 'can' does not necessarily imply 'must'. It is in this grey area that the pull of personal values can have its most pertinent and relevant moral purchase: lawyers are accorded the space and responsibility to act in a way that is most consonant with their own ethical compass. To abandon such responsibility and to ignore such practical possibilities is to shirk the challenge that can bestow upon lawyers, both collectively and individually, professional prestige and moral welfare.

To be an ethical lawyer, therefore, involves more than learning and applying a set of rules; it demands the cultivation of a critical reflection upon the professional role and responsibilities of lawyers. In short, a fully ethical practice requires an independent sense of moral virtue that involves the life-long development of personal moral character. Because there is no one answer to ethical dilemmas, it does not mean that reasoning can be abandoned or that 'anything goes'. A contextual approach simply insists that there is no final or objective answer to ethical problems, not that there are no answers. As the late Isaiah Berlin argued:

From this perspective, therefore, legal ethics is not about perfecting universalisable and enduring codes of conduct. It is about developing a transformative and pluralistic practice that respects the contingent and the particular and allows for diverse answers and appreciations. The traditional concepts and practices of honesty, confidentiality, trust, etc. remain most pertinent, but they are given meaning and bite as the context varies; they are fundamental, but not absolute values in the legal ethics vocabulary. As Lon Fuller pointed out, there is a vast difference between a professional duty that is based on 'duty' as opposed to 'aspiration' ${ }^{14}$ Whereas the former focuses on compliance with a set of rules and concentrates on what is not to be done rather than what ought to be done, the latter speaks in more positive terms and asks professionals to develop a style of practice that inspires ethical conduct rather than merely avoids unethical acts. The traditional emphasis 
on code-based morality breeds a mentality that is more concerned with delineating how far a lawyer can go without engaging in ethical conduct: it tends to privilege social conformity over efforts to build moral character.

In contrast to understanding the demands of legal ethics as being satisfied by the memorisation and rote-application of institutionalised responses to particular fact-situations, it ought to be about developing a framework within which to understand and reflect about the inevitable ethical dilemmas that arise as a professional. As such, legal ethics should be an integral dimension of what it means to be a good lawyer that pervades and infiltrates a professional's whole way of thinking and acting as a lawyer. In developing such a notion and practice of professional ethics, the challenge is neither to abandon a sense of personal morality and defer all ethical responsibility to the unique role and status of the legal professional nor to adhere entirely to the dictates of one's personal conscience and ignore the special responsibilities that attach to being a professional. It is a matter of creating a balance between the two such that it becomes possible to bring together the professional and the personal in a legal ethics that satisfies the pushes of personal morality and the pulls of professional conduct. To do otherwise is to either relinquish personal responsibility entirely to the self-interested norms of official codes of professional conduct or to ignore entirely the genuine framework of professional responsibilities that must influence and affect the dictates of personal conscience. It most definitely is not a choice between law and morality, such that the true professional must abandon all efforts to be a good person in being a good lawyer.

Accordingly, so legal ethics does not simply collapse into personal morality, there has to be recognition that 'role-differentiated behaviour' has a legitimate claim on the attention of those who strive to be ethical lawyers. Although lawyers must assume personal responsibility for their professional activities, it does not mean that they must only do as lawyers what they would do as an individual (which, in many cases, might turn out to be very extensive). It simply asks them to consider for themselves the extent of dissonance that a professionally-differentiated role should allow. Mindful of the social 
and political realities in which they offer their professional services, lawyers must confront the consequences of their choices about who to represent, the methods of representation and the broader consequences of their work. If lawyers did permit their own values and preferences to infiltrate all their work, it would mean that lawyers were abusing their privileges by rationing a valuable public service only to those whose views happen to coincide with their own. However, this does not mandate a wholescale abrogation of moral responsibility by lawyers. Instead, it suggests that lawyers should try to better integrate their professional and personal lives. Re-working the balance between role-morality and personal conscience, a fresh account of legal ethics would place the individual at the centre of the process and encourage lawyers to develop a critical morality that encompasses such pressing issues as 'what kind of lawyer do I want to be?' and 'what interests am I going to spend my life serving as a lawyer?'

In sum, asking lawyers to cabin their moral judgment, endangers the whole moral standing of the legal profession. In the traditional approach, there is very little space for reflection or engagement; reference to the Rules is intended to provide definitive and authoritative answers. My approach suggests that legal ethics has more to do with a practice of situated reasoning and with the interests, purposes and consequences of and for the participants and their contexts. Reliance on codes atrophies the moral intelligence and leaves lawyers adrift without a moral compass when those professional rules run out or give conflicting advice. My approach encourages continual reflection and therefore better prepares the lawyer for difficult situations. The other choice for the enlightened lawyer is to abandon the notion of a professionally-differentiated role morality entirely and incorporate all their personal values into the professional arena. This seems an unwise and undesirable move as lawyers will be abandoning their public trust and abusing their monopolistic privileges. The challenge is to integrate the demands of a professional role with the dictates of a personal morality and be able to construct important bridges between the two so that they can each support and fructify each other: one feeds off the other. To exercise sound professional judgement, it is necessary to resort to a well-honed and 
mature sense of moral acuity. Unless one subscribes to a very formalistic account of law, a familiarity with and sensitivity to moral issues is an essential quality that all lawyers must have if they are to advise clients about any particular area of law or what the courts are likely to do in any particular case. Without such resources, lawyers will be illequipped to fulfill the most basic skills of legal representation; they become only technicians, not advisers. To flinch this challenge or to settle it by default is to fail as both a matter of professional and personal responsibility; it will impoverish both professional and personal pursuits. As Robert Megarry concluded, "clients, of course, come and go; but your conscience does not, and you will have to live with it for the rest of your life."16

\section{Selecting Clients}

The circumstances in which one is asked or expected to demonstrate good professional judgement are infinite. Most have received or are beginning to receive considerable attention. However, client selection is one of the most important and most neglected issues for lawyers. Indeed, it can be strenuously argued that there is no more important issue for lawyers than how they are going to select the persons to whom they agree to provide their services because, once a client is taken on, the lawyer has become committed to a whole host of ethical and moral obligations. Lawyers and clients are engaged in a special relationship that lawyers cannot simply abandon as and when they choose. Moreover, all clients are entitled to the same level of competence and commitment from their lawyers. Once the lawyer-client relationship is established, a large part of the ethical die is cast. While the precise scope and substance of that relationship are imprecise, lawyers' options about what they are and are not prepared to do are severely curtailed and their obligation closely circumscribed. This is entirely reasonable as, under any realistic vision of professional responsibility, it would be unconscionable to take on clients and represent them in an incompetent or half-hearted way; this is a travesty of any kind of ethical expectation. Accordingly, the basis on which lawyers 
decide which persons or organisations to take on as clients has all kinds of ethical implications and salience.

For instance, in Canada, lawyers can choose to represent whomsoever they wish; the roster of potential clients is limitless. While the oath taken on call to the Bar often contains a commitment to "refuse no man's just cause", this is more of a token gesture of ceremonial window-dressing. Although the professional rules are imbued with a general sense that legal services are important and should be made available to everyone, there are no prohibitions on lawyers refusing to represent particular clients or causes. However, while it is arguable that it was the case under most general human rights laws, some jurisdictions have recently declared that lawyers must not make their choice of clients in a way that discriminates on the basis of race, gender, etc. This stipulation is well overdue. Other than this, however, lawyers are not formally constrained in their decision of how to allocate their services and expertise. It falls within that important grey area in which professional expectations and personal values merge. There are two major and inter-related ethical issues that pervade this important decision-is there an obligation to take unpopular cases; and is it ever professionally responsible to refuse certain cases? The fact that these questions have received relatively short shrift in the literature is troublesome in itself.

The first thing to note is that many young lawyers make this vital decision about the general kind of clients that they are going to represent without realising it. Any decision about the type of law practice or area of law that a young lawyer makes in choosing or accepting employment is critical. For instance, a decision to join a large urban firm that has mostly corporate clients has already ensured that the lawyer will be dealing with certain areas of law and from a certain perspective; being an environmental lawyer for some firms and, therefore, some clients (i.e., chemical corporations) is very different from working for other firms and other clients (i.e., environmental activists). Similarly, young lawyers who decide to set up their own firm have, unless they have established contacts and commitments, narrowed considerably the kind of clients and issues that they are likely 
to deal with, especially in their early years. In the following example, it is naive to believe that there are not ethical implications for the kind of lawyer that you want to become. Of course, the decision of what to do is not obvious: a decision either way can be defended in strong ethical terms. It is less of a case of condemning certain decisions and more of praising others. The key point is that, no matter how one decides, it has to be conceded that there is a pressing issue of legal ethics in play.

Problem I-Times are tight: you are a single parent and the bills are mounting up. With a mixed law school record and after being unemployed for six months, you are offered a reasonably well-paying job with a small firm whose main business is debt enforcement for large corporations and banks. As well as drafting air-tight loan agreements for the lenders, you are expected to be a vigorous and unyielding litigator. Would you take the job and why?

Although there is much rhetoric to the contrary, the traditional practice on client selection is that lawyers are neither under any obligation to take unpopular cases nor are they ethically compromised by the moral (un)worthiness of their clients' causes. Although lawyers are conferred with special privileges in pursuing their profession, they still retain considerable autonomy in how they utilise those privileges: the importance of the public's need for legal services does not submerge entirely lawyers' own sense of choice over how they work. However, once lawyers do make a decision to enter into a lawyer-client relation, their unswerving commitment to the cause of their clients is not to be interpreted as in any way supporting or condoning that cause. Unless they participate directly in unethical or illegal behaviour themselves, lawyers are to be treated as independent and moral agents; the sins of clients are not to be inflicted upon their lawyers. As Charles Fried argues, "as a professional person, one has a special care for the interests of those accepted as clients, just as his friends, his family, and he himself have a very general claim to his special concern."17

For some commentators, lawyers not only can, but should accept all requests for legal 
assistance, no matter how unpopular or unjust. The rationale for this is twofold. First, any other course of action would effectively deprive people of their legal rights; without legal representation, people's legal rights can be rendered hollow and ineffective. Secondly, for lawyers to determine the worth or merit of a legal claim at the outset is to usurp the function of the jury. While these arguments might have some bite in the criminal area, they have little to recommend them in civil matters. Moreover, even in the criminal area, it offers no compelling reason for why that lawyer has to be you. Although it is true that everyone has the right to be legally represented, this is not an argument as to why a particular lawyer should have a duty to be everyone and anyone's lawyer. Of course, there might be circumstances where lawyers believe that undeserving clients are entitled to their services because they believe that such clients should have a lawyer even though they cannot afford one or because they will be treated unfairly by the system. This eventuality might be particularly pressing where the lawyer is one of the very few local professionals with expertise in a particular area of law. It is not inconsistent to suggest that, while a lawyer might prefer to represent (or not represent) certain types of client, they might also recognise that such a preference might be outweighed in some special circumstances-personal judgement is nuanced and its exercise is heavily contextualised.

According to Duncan Kennedy, ${ }^{18}$ the right not to take clients has a much wider moral ambit than simply refusing to represent people or organisations which you think have evil intentions or of whose activities you disapprove. He maintains that lawyers should take full responsibility for the clients that they take and the causes that they advance: it is ethically wrong to argue a case or a cause that will do more harm than good if you think that your client should not be in court in the first place or that your client should lose. In particular, you should not represent clients who are using technical defences to avoid justified liability or who are enforcing their valid legal rights in a bad cause. For Kennedy, "you are tarred with the bad actions of clients that you facilitate in your work as a lawyer." ${ }^{19}$ Working against/for unionisation if you are pro/anti-union or 
advising for the postponement/implementation of environmental controls if you are pro/anti-environmental rights is something that lawyers should not do, and they should not do it as a matter of professional ethical responsibility. This does not mean that lawyers should only choose to represent clients of which I or anyone else would approve. It simply means that lawyers should only represent clients or causes that they are prepared to defend as being more rather than less beneficial for society.

The argument that lawyers should have an obligation to take any and all clients founders on a number of critical reefs. First, most lawyers draw the line at representing clients for free. This is not unreasonable; lawyers are not charities. There is no particular reason why some lawyers should shoulder singly a problem of non-accessibility that has public and collective causes and that could be dealt with by a more compelling pro bono obligation. If the profession is to have any real chance of matching its rhetoric of service to the reality of social need, lawyers must begin to take seriously the obligation to provide their services at reduced rates, to take legal aid clients, and to engage in pro bono work. It is not enough to heap praise on those lawyers who undertake such work. This obligation must be built into the basic ethical fabric of professional responsibility. 'Access to justice' is a hollow slogan unless there is genuine access to legal services. The legal profession is too quick to trumpet the moral obligation to perform pro bono work, but very slow at fulfilling it. Even when it is done, it is seen as a virtuous act of noblesse oblige rather than a basic responsibility that comes with being a lawyer. ${ }^{20}$

Secondly, it is true that there is an obligation on the legal profession to ensure that people have access to lawyers; it is a hypocritical process and profession that trumpets people's rights, but fails to provide available means to exercise them fully. However, while the profession has such a collective responsibility, this does not provide an obvious answer as to why any particular lawyer should be obliged to take on any particular client. This argument only has bite where the lawyer is the 'last lawyer in town $^{21}$ and the client has no other means of legal representation to which to turn. Nevertheless, there are clearly cases where people have been refused representation by 
lawyers as a result of considerations that are unrelated to their legal cause. While some unpopular clients or causes are going without legal representation, it is as likely the case that more potential clients fail to get a lawyer because of their inability to pay than because of the unpopularity of their case. Again, provided that lawyers are not using illegal criteria to make such decisions (e.g., race, gender, etc.) and there are no extenuating circumstances (e.g., the only available lawyer), it seems reasonable to allow lawyers a degree of choice in selecting the persons or organisations whom they will represent.

In the following situations, lawyers are presented with difficult decisions and the way in which they respond to them will reveal much about their approach to legal practice and their commitment to professional responsibility:

Problem 2-A well-dressed couple come to your office to seek your services. They tell you that they made an arrangement with an elderly couple to caretake a property they own while they were out of the country for a year. Now that they have returned, they no longer want to pay the couple the $\$ 3000$ that they had informally promised to pay them, even though the elderly couple had done the work in exemplary fashion and now need the money. Do you agree to help them to get out of the deal? Would it make a difference to you, if these people were already clients of yours in other matters, they were willing to pay you handsomely, they had discovered that the elderly couple were cheating Revenue Canada, you were short of clients, etc.?

Problem 3-At a meeting of your law firm, it is suggested henceforth that members of the firm should represent only women in spousal abuse cases. Do you agree with such a policy? Does it make any difference if this policy is adopted by a publicly-funded, legal-aid clinic?

Again, in both situations, there are no easy or pat answers. It will be for each lawyer to 
make a contextualised decision that he or she is prepared to defend. Most importantly, lawyers should appreciate that there is no position of no-decision: whatever decision they make will reflect and implicate a certain stand on the nature and extent of ethical obligations in the practice of law. Moreover, because one lawyer is or is not prepared to act in one way or another is not in itself cause to criticise others who do not take a similar stance as professionally unethical. At most, it is an occasion on which lawyers can agree to disagree as well as work to persuade each other of the moral superiority of their own position.

In general, it is no excuse or justification to argue that, if you do not take the case, somebody else will or that it is a wealthy client who will generate sizeable income-these are weak efforts at ethical rationalisation. Nevertheless, although economic logic is not of itself a decisive moral imperative, it can be a contextual factor in any decision to accept certain clients; a moral absolutist stance is as unrealistic as one that reduces ethical reflection to economic calculation. While it is important that your clients have a legal basis for their action, it is only a necessary, but not sufficient condition for your involvement. Also, because lawyers influence the law's content through their advocacy, they must take some responsibility for the way in which the law develops and unfolds. For instance, tax lawyers _ earn their keep by advising rich clients on how to get around tax laws and, in the process, affect the interpretation of the law itself, often bringing about legislative changes and revisions. Often, tax lawyers are consulted by the government on the wisdom or merit of particular changes to the tax system. It ill-behooves such lawyers to pretend that they merely respond to a system that functions independently of them. Because tax lawyers largely represent the business and investment sector, they do little to help the rest the population and might indeed have some responsibility for shifting the tax burden on to the poorer parts of the population. ${ }^{22}$

Before taking on any clients, it seems ethically incumbent upon lawyers to talk to them. This need not be a one-way lecture to the potential client about the lawyers' ethical values, but it might be a conversation in which lawyer and client outline their basic 
expectations of each other. Q!iestions that lawyers might ask before taking on a client include whether the objective of the case is worthy and whether the means that might be required are something that they can and are prepared to do. Of course, it will be important that lawyers inform potential clients of the ethical limits that they place on their provision of legal services; this might include negotiation tactics, cross-examination style, etc. For instance, even if a prospective client has a strong case in a matrimonial dispute, there seems no particular reason why lawyers should be obliged to accept them as clients if they want their lawyer to take the most aggressive and unyielding approach to their spouse. While there is nothing necessarily wrong with lawyers adopting such an approach, it will be incumbent upon them to take personal responsibility for such an approach and not hide behind the rhetoric of the traditional model. Such matters must, of course, be dealt with before the lawyer-client relationship is established, rather than after it; it is reasonable that clients are entitled to expect lawyers to act in accordance with traditional perceptions of 'zealous advocacy' unless their lawyers inform them differently.

The ethical premise that underlies this collaborative suggestion is that lawyers should treat their potential clients as moral persons who are capable of engaging in debate and changing; the hope is that, in doing so, lawyer and client together will create pressure to push up, not squeeze down, the ethical standards of professional conduct. At the same time, it is unrealistic to expect that every lawyer will, like Socrates, only be guided by the need to do right rather than wrong: most lawyers are reasonably concerned about their jobs, paying their mortgages, providing for their children, etc. Furthermore, it is impractical to believe that lawyers and clients will have to share a whole ethical outlook on life to be able to establish a workable and moral professional relationship. It might be that lawyers will need to make an important distinction between 'values' (i.e., preferences that are to be weighed in any ethical decision) and 'convictions' (i.e., baselines against which other values and preferences are to be set). For example, while lawyers might refuse to represent a particular side in the abortion struggle, they might not have a difficulty in representing such persons in unrelated property transactions. 


\section{Personal Responsibility}

Sadly, the traditional vision of lawyering tends to be as much a convenient device by which to finesse the hard questions of practice as a useful tool with which to confront and grapple with them. While the idea of professionalism ought to be a reliable guide to lawyers, this does not imply that its content and orientation must be unchanging; "it makes sense to view professionalism not as a fixed ideal, but rather as an ongoing struggle." 23 In many ways, professional Rules do little service in the day-to-day practice of lawyers as a result of their generality and vagueness: ethical problems are often too complex and subtle to lend themselves to formulaic resolution. At the heart of my proposal, therefore, is the central question whether it is ever acceptable that lawyers might, can or should act in a professional capacity in such a way that would be contrary to their own moral values. My answer is that there ought to be a special and symbiotic relation between personal morality and professional expectations. However, in line with the overall contextualised recommendations of this pragmatic approach, the nature of this relation will be revisable and organic; it will develop and change as lawyers adapt themselves and their professional persona to contingent circumstances. Some of the more important recommendations for change and revision include:

- There must be a shift of emphasis from professional regulation to personal responsibility. The ambition is not to promote a particular set of ethical outcomes or inculcate a specific mode of professional responsibility. It ought to be to challenge students and lawyers to develop a professional modus vivendi of their own that constructs as it constantly challenges and re-works an appropriate professional attitude and practice.

- In the same way that there is no one or unchanging way to be a good person, there is no one or unchanging way to be a good lawyer. Each and every lawyer must be capable of developing a style and substance of lawyering that incorporates a continuing 
dialogue

-with oneself, clients, other lawyers, other professionals, and the community at large about what counts as good lawyering. In many so-called hard cases, there is rarely an obvious or incontestable path to follow.

- The professional Rules do not and cannot relieve lawyers of the continuing responsibility to exercise their own professional and moral judgement about the appropriate course to follow. Unthinking compliance with the specified Rules does not guarantee that lawyers will develop a sense of ethical judgment: professional morality is more than lawabiding conformity. The Rules are only a starting-point or resource in the broader debate about appropriate ethical behaviour: they act as the outside limits within which debate can and must occur.

- Each individual lawyer and student must justify their sense of professional responsibility through their actions rather than justify their actions by reference to the ideals of professional responsibility. If the legal profession is to live up to its own cherished ideals and to reclaim its reputation as an honourable undertaking, it must challenge each of it present and future members to take this task seriously.

- There is always the personal ethical challenge of determining whether, because the Rules allow certain conduct, the individual lawyer should reflect on and perhaps refuse to operate in certain ways. The fact that the Rules allow lawyers to ignore the interests of other parties entirely does not mean that it is a morally unimpeachable course to follow: 'can' does not necessarily imply 'must'.

- Lawyers must be prepared to answer for the ethical choices which they make and the legal practice in which they engage. An explicit and enduring focus on the cultivation of a strong sense of professional purpose and judgment must be pursued and institutionalised.

In conclusion, therefore, my primary recommendation has been to urge lawyers to take personal responsibility for what they say and do in their professional capacities. 
Although it seems a rather modest proposal, it has traditionally been treated as being of radical import and implication. ${ }^{24}$ In a manner of speaking, what counts as the professional model is little more than the calcified values of one particular group of lawyers at one particular point in time; personal preference has been dignified with the institutional imprimatur of professional imperative. As with so much else in law, certain established groups have been able to pass off their ethical accents as the neutral voice of the legal profession. However, as the composition of the profession begins to change and diversify, it is important that there is a greater fit between the professional expectations of lawyers and their own personal consciences. Today's lawyers should have the same privileges as yesterday's lawyers -to practice law in such a way that their daily routines and decisions comport more closely to their own best sense of themselves as moral individuals. In this way, being an ethical lawyer can be less of a conforming chore and more of an aspiring responsibility. Moreover, so emboldened, individual lawyers might impact on the collective convictions of their colleagues and so enhance the overall reputation of the legal profession.

In the same way that "good oratory is a good person speaking well,"25 so good lawyering is a good person acting well. As trivial and trite as this may seem, it is the best advice that can be given to the fledgling lawyer and the most compelling injunction to the jaded lawyer. It offers no magical guide as to what to do in any specific or conflicted situation because there is none to be given. It is for each person to arrive at an informed and conscientious decision in accordance with their own political and moral lights. The objective is not to chastise lawyers simply because they are corporate lawyers or represent rapists and bigots: it is to encourage each lawyer to take responsibility for the clients they take, the causes they fight for and the tactics they use. A sound account of legal ethics and professional responsibility must encourage lawyers to live up to their better ethical selves, not excuse them from that challenge.

It is surely the case that, in answering Socrates's famous question about "how 
should one live?", lawyers cannot respond by simply mumbling that it is acceptable to do whatever is not expressly prohibited by law or disallowed by the professional codes. This is not so much an ethical stance as an abnegation of one. As Hazard observes, "when all has been said, the fact will remain that a lawyer's ethical deliberations are a process of personal thought and action. ${ }^{126}$ In that process, students and lawyers must be prepared to answer for the ethical choices which they make and the legal practice in which they engage. Simply pointing to some rule is never enough on its own. Instead, there must be a greater acceptance of the fact that good professional judgement cannot be left to the untutored and catch-as-catch-can approach of the present legal community. An explicit and enduring focus on the cultivation of a strong sense of professional purpose and judgment must be pursued and institutionalised. 


\section{Notes}

${ }^{1}$ Osgoode Hall Law School, York University, Canada. This essay is based upon a public lecture given at Cardiff Law School, University of Wales, in March 1998: I am grateful for its warm hospitality and critical col- legiality. The essay also builds on an earlier piece, entitled "Legal Ethics For A Fragmented Society: Between Professional and Personal" (1998) 5 International Journal of the Legal Profession 175-92 and forms part of a forth- coming book, entitled Legal Ethics and Professional Responsibility: An Introduction (Toronto, Irwin Books, 1999). ${ }^{2}$ Lord Bolingbroke, On the Study and Use of History, Letter 5 (1739).

3 J. Sammons, Jr., Lawyer Professionalism (Durham, N. Carolina, Carolina Academic Press, 1988) p. 47.

4 A. Kronman, The Lost Lawyer: Failing !Mais of the Legal Profession (Cambridge, Ma, Harvard University Press, 1993).

5 See Aristotle, Nichomachean Ethics (Indianapolis, Hackett, 1985; trans. T. Irwin), Book 6.

${ }^{6}$ D. Luban and P. Milleman, "Good Judgment: Teaching Ethics in Dark Times", (1995) 9 Georgetown Journal of Legal Ethics 31.

7 See M. Freedman, Lawyers' Ethics in an Adversary System (Indianapolis, Bobbs-Merrill, 1975) and A. Goldman, The Moral Foundations of Professional Ethics (Totowa, NJ, Rowman \& Littlefield, 1980).

${ }^{8}$ See Freedman, ibid, and, in a more qualified form, R. Wasserstrom, "Roles and Morality" in D. Luban (ed) The Good Lawyer (Totowa, NJ, Rowman \& Allanheld, 1983).

${ }^{9}$ See H. Arthurs, "Oimbing Kilimanjaro: Ethics For Postmodern Professionals" (1993) 6(1) Wtstminsttr Affairs 3.

10 See W. Simon, "The Trouble with Legal Ethic." (1991) 41 Journal of Ltgal Education 65 and Schiltz, "Legal Ethics in Decline" (1998) 82 M innesota Law Rtvitw 705 at pp. 713-18.

11 See generally "Symposium-Critical Theories and Legal Ethics" (1993) 81 Gtorgttown Law Journal 2457ff. and "Symposium-Teaching Legal Ethics" (1995) 58(3 \& 4) Law and Contemporary Problems.

"Since some values may conflict intrinsically, the very notion that a pattern must in principle be discoverable in which they are all rendered harmonious is founded on a false a priori view of what the world is like ... The need to choose, to sacrifice some ultimate values to others, turns out to be a permanent characteristic of the human predicament." 13

${ }^{12}$ See W. Simon, Tht Practiu of Justiu: A Theory of Lawyers' Ethics (Cambridge, Ma, Harvard University Press, 1998) pp.197-203.

13 I. Berlin, Four Essays on Liberty (Oxford, Oxford University Press, 1969), li.

${ }^{14}$ See L. Fuller, Tht Morality of Law (New Haven, Conn, Yale University Press, 1969).

${ }^{15}$ See A. Esau, "Teaching Professional Ethics and Responsibility at Law School: What, How, and Why?" in

R. Matas \& D. McCawley, eds., Legal Education in Canada: reports and background papers of a National Conference on Legal Education held in Winnipeg, Manitoba, October 23-26, 1985 (Montreal: Federation of Law Society of Canada, 1987) 308.

16 R. Mcgarry, "Convocation Address", (1983) 17 LSUC Gautte 41 at p.44.

17 C. Fried, "The Lawyer As Friend: The Moral Foundations of The Lawyer-Oient Relation" (1976) 85 Yak L] 1060 .

${ }^{18}$ D. Kennedy, "The Responsibility of Lawyers for the Justice of Their Causes" (1987) 18 Texas Tech Law Review 1157.

${ }^{19}$ Ibid. at p.1159.

${ }^{20}$ Of course, any proposal to require lawyers to do compulsory pro bono work is not without problems. Apart from the ideological argument about infringing lawyers' autonomy, it is seen to devalue the altruistic nature of the work and it is likely to operate in an inequitable way in that its burden will be greater for the already economically-marginalised practitioner than the partners in large firms. Moreover, it might lead to the wrong kind of work being done and lawyers doing work that they are not trained to do (i.e. corporate lawyers representing poor clients for welfare claims). While these objections cannot be ignored, they are insufficient to invalidate the worth of such a proposal: the transforrnative value of having establishment lawyers appear in provincial courts ought not to be under-estimated. Nevertheless, in response to the traditional concerns, it might be possible, for example, to introduce a coupon scheme whereby clients are directed to appropriate lawyers and those lawyers who do not receive enough pro bono coupons will be required to pay into a pro bono fund an equivalent amount to the hours not done. See D. Luban, Lawytrs and Justict: An Ethical Study (Princeton, NJ, Princeton University Press, 1988) pp.277-82. See also S. Lubet and C. Stewart, "A 'Public Assets' Theory of Lawyers' Pro Bono Obligations" (1997) 145 Univmity of Pmnsylvania Law Rtvitw 1245.

${ }^{21}$ C. Wolfram, Modtrn Ltgal Ethics (St Paul, Minn., West Publishing, 1986), p. 222.

22 See L. McQuaig, Behind Cloud Doors (Markham, Ontario: Penguin Books 1987) pp. 95-102.

23 D. Rhode, "The Professionalism Problem" (1998) 39 William (5 Mary Law Review 283

${ }^{24}$ See, for example, Freedman and Goldman, supra, n.7.

${ }^{2}$ S Qy.intilian, Institutio Oratoria, (Cambridge, Ma, Harvard University Press, H. Butler trans. 1961), Book XII, s.1.1.

26 G. Hazard, "Personal Values and Professional Ethics" (1992) 40 Cleveland State Law Review 133 at p. 140. 